\title{
Computer-based diagnosis of illness in historical persons
}

\author{
${ }^{1} \mathrm{TJ}$ Peters, ${ }^{2} \mathrm{P}$ Garrard \\ ${ }^{1}$ Honorary Senior Research Fellow, Institute of Archaeology and Antiquity, University of Birmingham; ${ }^{2}$ Reader in Neurology, Stroke and \\ Dementia Research Centre, St George's, University of London, UK
}

\begin{abstract}
Retrospective diagnosis of illness in historical figures is a popular but somewhat unreliable pastime due to the lack of detailed information and reliable reports about clinical features and disease progression. Modern computer-based diagnostic programmes have been used to supplement historical documents and accounts, offering new and more objective approaches to the retrospective investigations of the medical conditions of historical persons. In the case of King George III, modern technology has been used to strengthen the findings of previous reports rejecting the popular diagnosis of variegate porphyria in the King, his grandson Augustus d'Esté and his antecedent King James VI and I. Alternative diagnoses based on these programmes are indicated. The Operational Criteria in Studies of Psychotic Illness (OPCRIT) programme and the Young mania scale have been applied to the features described for George III and suggest a diagnosis of bipolar disorder. The neuro-diagnostic programme SimulConsult was applied to Augustus d'Esté and suggests a diagnosis of neuromyelitis optica rather than acute porphyria with secondarily multiple sclerosis, as proposed by others. James $\mathrm{VI}$ and I's complex medical history and the clinical features of his behavioural traits were also subjected to SimulConsult analysis; acute porphyria was rejected and the unexpected diagnosis of attenuated (mild) Lesch-Nyhan disease offered. A brief review of these approaches along with full reference listings to the methodology including validation are provided. Textual analysis of the written and verbal outputs of historical figures indicate possible future developments in the diagnosis of medical disorders in historical figures.
\end{abstract}

KEYWORDS King George III, King James VI/I,Augustus d'Esté, computer diagnostics, acute porphyria, neuropsychiatric disorders

\author{
Correspondence to TJ Peters \\ Iron Lock Cottage, \\ Beeston Brook, Tiverton, \\ Tarporley, Cheshire \\ CW6 9NH, UK
}

e-mail timothy@ironlock.f2s.com

DECLARATIONS OF INTERESTS No conflicts of interest declared.

\section{INTRODUCTION}

The results of our research ${ }^{1-8}$ have challenged the claims that George III and many of his relatives suffered from variegate porphyria. ${ }^{9-13} \mathrm{We}$ believe that the exponents of the porphyria diagnoses have been misled, a fact that raises further important questions. In the first place, why were medical historians misled, and what was the reason for the incorrect diagnosis? Secondly, what differential diagnosis was considered? Thirdly, what lessons can be learned from other reports of diagnoses of historical figures? Finally, has the incorrect diagnosis inhibited other studies of the King's behaviour and actions during his reign? The answers to some of these questions raise issues that are important, particularly with the growing contemporary interest in diagnostic errors. ${ }^{14}$

\section{KING GEORGE III (I738-|820)}

In 1965 Ida Macalpine and her son Richard Hunter, both general psychiatrists and amateur historians, claimed that King George III had not suffered from the primary psychiatric disorder manic-depressive psychosis which had been proposed by psychiatrists in the USA. ${ }^{15-18}$ They claimed instead that he suffered from the rare inherited metabolic disorder acute intermittent porphyria, ${ }^{19}$ though this diagnosis was later changed to the even rarer and milder condition, variegate porphyria. ${ }^{20}$ The errors in Macalpine and Hunter's diagnostic reasoning have recently been investigated in detail ${ }^{2}$ and some of the causes and consequences of their misdiagnosis have been discussed. ${ }^{5}$

Macalpine and Hunter discounted many signs, symptoms and features of the King's recurrent illness that were incompatible with their diagnosis. More significantly, they did not discuss their diagnostic process, formulate any differential diagnoses, or attempt to show how their proposal met objective criteria such as that available in the International Classification of Disease (ICD) and the Diagnostic and Statistical Manual of Mental Disorders (DSM). They rejected the accepted diagnosis of manicdepressive psychosis because mania was '...no more specific a description of an abnormal mental state than 
"fever" was of an abnormal physical one'. In spite of these failures of process, the diagnosis of porphyria gained widespread support, even though the diagnostic processes followed would not be acceptable under today's standards.

\section{The OPCRIT system}

George III clearly met the diagnosis of recurrent mania as determined by the DSM-III and DSM-IV-TR and ICD10 criteria. ${ }^{3,4}$ The operational criteria in studies of psychiatric illnesses (OPCRIT) system developed by Peter McGuffin and colleagues is used for the diagnosis of the major psychiatric disorders from patient case notes and was developed as part of a programme for investigating genetic components of bipolar disorder and schizophrenia. ${ }^{21,22}$ It is well-validated and widely used for research purposes. It has a 90 -item input checklist and provides an output of 12 classification systems. A recent study has successfully applied the OPCRIT system to a selection of authors and poets from the fourteenth to the twentieth centuries, some with indications of mental disorders, ${ }^{23}$ and more recently to members of a consanguineous eighteenth-century Portuguese Royal family with severe psychiatric disease. ${ }^{24}$

The results of the OPCRIT studies of King George's recurrent episodes of mental illness are shown in Table I. It was claimed that he had four significant episodes of mental illness: in 1788-9, 180I, I804 and I810-1I. There are contemporary letters and diaries but no detailed medical records for the 1804 episode. ${ }^{9,10}$ There were thus insufficient data from the 1804 episode for an OPCRIT-based diagnosis, illustrating an important constraint in the use of this programme. In contrast, the data available for the $|788-9| 80 \mid$, and $|8| 0-1 \mid$ episodes are sufficient to give clear diagnoses under the principal diagnostic categories available. The diagnoses for 1788-9 and $180 \mathrm{I}$ include mania and mania with psychosis; the $|8| 0-1 \mid$ episode appears less severe with hypomania the predominant diagnosis. This episode was followed by a decade of chronic mental ill health. It has been suggested that from 1810 until his death on 29 January 1820, the King suffered from chronic mania with accompanying dementia., ${ }^{3,4}$

\section{The Young mania scale}

The Young mania rating scale is a well-validated questionnaire widely used for clinical and research purposes. ${ }^{25}$ Unfortunately a detailed assessment of the King by a single observer during this episode is not available. He was initially under the care of Sir George Baker and a group of Royal physicians, but no details of their observations remain. However he was also attended by an equerry, Robert Greville, who kept a detailed diary. ${ }^{26}$ Highly detailed assessments become available following the King's removal to Kew Palace and the summons of Rev Dr Francis Willis and his two medically qualified sons, and are available in the British Library. ${ }^{27}$ A comparison of Greville's records of the King's symptoms, including sleep patterns, with those documented in Willis's reports show general agreement ${ }^{3}$ and this is summarised in an aggregate sequential score in Table 2. This score indicates that during his most disturbed phase he would be classified as severity rating IV (Table 3). This is the most severe category reported by Young and his colleagues.

The OPCRIT and Young scores were the result of joint observations by TJP (who has a detailed knowledge of the King's illness) and an experienced psychiatrist with an interest in the history of his specialty (Dr Allan Beveridge).

\section{The Charleson index}

A further example of the use of modern indices to assess the King's health and prognosis during the 1810 20 episode can be obtained using the Charleson index. ${ }^{28}$ This well-validated and useful clinical inde ${ }^{29,30}$ takes into consideration patient age and co-morbid factors in predicting survival over the subsequent decade. At the age of 70 , and with evidence of early cognitive impairment, George III has a score of four with a predicted ten-year survival of $50 \%$. His actual survival for ten years in the early nineteenth century reflects well on the level of care provided but also indicates the absence of any underlying serious medical condition.

TABLE I Operational criteria in studies of psychotic illness (OPCRIT) analysis of King George III's mental health disorders in |788-9, $180 \mid$ and |810-II

\begin{tabular}{|l|l|l|l|}
\hline Criteria & $\mathbf{I 7 8 8 - 9}$ & $\mathbf{I 8 0 I}$ & $\mathbf{I 8} \mathbf{~} \mathbf{0}-\mathbf{I} \mathbf{I}$ \\
\hline DSM III & Mania with psychosis & Mania with psychosis & Mania with psychosis \\
\hline DSM IIIR & Manic episode with psychosis & Manic episode with psychosis & Hypomanic episode \\
\hline DSM IV & Manic episode with psychosis & Manic episode with psychosis & Hypomanic episode \\
\hline Taylor and Abrams & Mania & Mania & Mania \\
\hline ICD-I0 & Mania with psychosis & Mania with psychosis & Hypomania \\
\hline RDC & Mania & Mania & Hypomania \\
\hline $\begin{array}{l}\text { DSM= Diagnostic and Statistical Manual of Mental Disorders; ICD= International Classification of Disease; } \\
\text { RDC= Research Diagnostic Criteria. }\end{array}$ &
\end{tabular}


TABLE 2 Serial Young mania scores for George III's I788-9 episode of acute mania

\begin{tabular}{|l|c|c|c|c|}
\hline Date & $\begin{array}{c}\text { Sir George Baker, } \\
\text { MD }\end{array}$ & Col Robert Greville & $\begin{array}{c}\text { Willis family } \\
\text { doctors }\end{array}$ & Aggregate (士5) \\
\hline 24-30 October 1788 & 24 & & & 25 \\
\hline 19-24 November 1788 & & 37 & & 35 \\
\hline 23-8 December 1788 & & 39 & 36 & 40 \\
\hline 23-7 January 1789 & & 15 & 16 & 15 \\
\hline 23-8 February 1789 & 5 & 7 & 5 \\
\hline 17-26 March 1789 & & & 5 & 5 \\
\hline
\end{tabular}

TABLE 3 Median rating scales of patients with acute mania ${ }^{26}$

\begin{tabular}{|l|c|c|c|c|}
\hline Severity & I & II & III & IV \\
\hline Global rating & $0-1.5$ & $2.0-2.5$ & $3.0-4.0$ & $>4.0$ \\
\hline No. & II & 7 & II & 6 \\
\hline Mean rating scale & 12.5 & 19.3 & 25.5 & 37.9 \\
\hline
\end{tabular}

\section{AUGUSTUS D’ESTE (I794-I848)}

D'Esté was the son of George III's sixth son, Augustus Fredrick, Duke of Sussex (1773-1843), and his morganatic wife, Lady Augusta Murray. At the age of 28 d'Esté developed a chronic but remitting and relapsing neurological condition that has been claimed to be the first recorded case of multiple sclerosis (MS). ${ }^{31-5}$ D'Esté wrote a detailed diary of the signs and symptoms of his illness and the medical interventions. Some of the clinical features were atypical for MS, particularly the apparent absence of nystagmus, intention tremor, scanning speech or cognitive impairment. On this basis Macalpine and Hunter ${ }^{9}$ suggested that he (and therefore his father and grandfather) all suffered from acute porphyria. A detailed re-assessment of his neurological condition has therefore been undertaken using the computer-based diagnostic programme SimulConsult Neurological Syndromes.

\section{The SimulConsult Neurological Syndromes programme}

This programme provides a weighted differential diagnosis from a database of 2,500 diseases, and the demographic, clinical and laboratory information associated with each. The database includes all the acute porphyrias and a range of demyelinating disorders. ${ }^{36-9}$ Figure I shows the results of inputting the principal features of d'Esté's condition as reported in the patient's diary. The resulting principal diagnosis was neuromyelitis optica (Devic's syndrome), with MS as a less likely alternative; variegate porphyria does not appear in the differential diagnosis. Interestingly the reports supporting the claim that d'Esté was the first recorded case of MS do not include neuromyelitis as a potential alternative, even though the condition was recorded in 1894 by Devic and Gault ${ }^{40}$ and is listed as the principal differential diagnosis in suspected MS in standard neurological textbooks. ${ }^{41} \mathrm{~A}$ possible reason for this omission is that until relatively recently a diagnosis could only be made on clinical grounds, which emphasised the myelitic and optic components. Modern criteria, however, are based on the condition's autoimmune aetiology, allowing its clinical spectrum to be broadened. ${ }^{42}$

\begin{tabular}{|l|l|}
\hline Differential diagnosis & \multicolumn{1}{c|}{ Add findings } \\
Diseases & Patient's findings \\
\hline Devic neuromyelitis optica (NMO) \\
\hline Multiple sclerosis \\
\hline Acute transverse myelitis \\
\hline Vitamin B12 (cobalamin) deficiency (pernicious anem \\
\hline Vitamin B1 (thiamine) deficiency (beriberi), dietary \\
\hline Amyotrophy, hereditary neuralgic, with predilection f \\
\hline Porphyria, acute intermittent \\
\hline Leber hereditary optic neuropathy (LHON) \\
\hline Strachan amblyopia, painful neuropathy, orogenital d \\
\hline Cerebrotendinous xanthomatosis (CTX, cerebral cho \\
\hline Adrenomyeloneuropathy (AMN) \\
\hline CMTX5: Charcot-Marie-Tooth disease (PRPS1-relat \\
\hline Leprosy (Hansen's disease) \\
\hline Herpes simplex (HSV) meningoencephalitis (herpetic \\
\hline SPG15: Kjellin spastic paraplegia and retinal degene \\
\hline
\end{tabular}

FIGURE I Results of inputting principle features of d'Este's condition as reported in the patient's diary, into SimulConsult ${ }^{\circledR}$

SimulConsult offers the option of adjusting the case differential diagnosis with respect to the relative incidence of the diseases. If this is done for d'Esté, MS (with an incidence 17 times that of neuromyelitis optica) becomes the principal diagnosis, with neuromyelitis the second most likely. ${ }^{6}$ We believe that this approach should be used with caution, especially with historical persons and those of non-European ethnicity, in whom disease risk and clinical features may differ significantly from those observed in the present. ${ }^{43,44}$ 


\section{KING JAMES VI AND I (1566-I625)}

The absence of a diagnosis of porphyria in George III makes it very unlikely that any of his relatives, antecedents and descendants, suffered from the condition, so a detailed re-assessment of the claimed cases would be unnecessary as well as impractical. ${ }^{9-13,45-7} \mathrm{~A}$ single case study of the medical condition(s) of James $\mathrm{VI}$ and $\mathrm{I}$ is, however, of value given the quality of the medical information available about him and the interest in his unusual behaviour. A detailed medical report on King James, prepared by Theodore de Mayerne (an early seventeenth-century physician in England and a longstanding physician to the Royal family) has been preserved in full. In 1623, de Mayerne had to return to Switzerland to attend to some family business and left a detailed medical history and report with diagnoses and treatment protocols for the local physicians who would be looking after James during his absence. A full translation of this report is now available, providing detailed information on his health and the diagnostic process undertaken., ${ }^{7,8}$ Until recently only a partial translation was available to medical historians for use in their research. ${ }^{48}$

\section{The SimulConsult Neurological Syndromes programme}

King James had a complex medical history with problems originating in his childhood and persisting throughout his life, suggestive of a multi-system disorder with movement, behavioural, renal, locomotor and endocrine features. ${ }^{8}$ The following principal clinical features were selected for input into SimulConsult: 59-year-old male with motor development delay from the age of around one year old, renal calculi onset aged 40 years, and abnormal speech of unknown onset. As with Augustus d'Este, SimulConsult was employed in this case to objectively verify or disprove the claimed diagnosis of variegate porphyria. The most unexpected results are shown in Figure 2. None of the acute porphyrias (particularly variegate porphyria) were among the first I5 differential diagnoses. The mild neurological form of Lesch-Nyhan disease followed by the more classical forms of the condition were the only significant diagnoses offered. Rickets, poliomyelitis, Charcot-Marie-Tooth disease or cerebral palsy with athetoid features, all conditions that have also been suggested, ${ }^{49,50}$ did not feature in the list of possible diagnoses.

Lesch-Nyhan as originally described is an X-linked disorder with marked neurological features and mental retardation. ${ }^{51}$ Subsequent studies have identified a defect in purine metabolism with reduced activity of the purine salvage pathway enzyme, hypoxanthine phosphoribosyl transferase. ${ }^{52}$ More recent studies have identified attenuated (milder) variants with significant residual enzyme activity. ${ }^{53} \mathrm{~A}$ key feature of the mild

\begin{tabular}{|l|}
\hline Differential diagnosis \\
Diseases Add findings \\
\hline Lesch-Nyhan disease, mild neurological (Group 2 HPR \\
\hline Lesch-Nyhan disease, classical (Group 4 HPRT1 defic \\
\hline Lesch-Nyhan disease, severe neurological (Group 3 Hr \\
\hline Alkaptonuria (alcaptonuria) \\
\hline Wilson disease (hepatolenticular degeneration) \\
\hline Mucolipidosis III $\gamma$ (atypical, variant pseudo-Hurler po \\
\hline Leg length disparity \\
\hline Rheumatoid arthritis, juvenile \\
\hline Mucolipidosis III $\alpha / \beta$ (pseudo-Hurler polydystrophy) \\
\hline Alström Syndrome (Alström-Hallgren) \\
\hline Systemic lupus erythematosus (SLE) \\
\hline Multiple epiphyseal dysplasia, dominant (EDM1, EDM \\
\hline Fibromyalgia \\
\hline PRS superactivity, infantile (phosphoribosylpyrophosp) \\
\hline Stickler syndrome (arthroophthalmopathy) \\
\hline Marfan syndrome, infantile \\
\hline Marfan syndrome, classical \\
\hline
\end{tabular}

FIGURE 2 Results of inputting principle features of King James' condition into SimulConsult ${ }^{\circledR}$.

variants is that sufferers may lack cognitive dysfunction, particularly those with only mild neurological symptoms. A key feature of untreated Lesch-Nyhan disease is hyperuricaemia with renal calculi characteristic of uric acid crystals (cloudy red urine with sandy-coloured grains), as observed in James, ${ }^{54,55}$ a feature that has been unaccountably overlooked in previous attempts to reach a diagnosis.

\section{The adult Asperger assessment diagnostic criteria}

Maladaptive behaviour is a frequent feature of attenuated Lesch-Nyhan and this would be consistent with some of James's characteristic conduct. The descriptions of him as 'the wisest fool in Christendom'56 and 'one of the most complicated neurotics to sit on either the English or the Scottish throne' ${ }^{\prime 57}$ aphoristically describe this condition. James's behaviour and his apparently high intelligence are consistent with a diagnosis of Asperger's syndrome, which may also occur in attenuated LeschNyhan disease, and he meets the DSM-IV and ICD-10 criteria for the condition. ${ }^{8}$ Asperger's syndrome is a component of the autistic spectrum disorders, characterised with little or no evidence of cognitive impairment. The use of the adult Asperger assessment diagnostic criteria developed by Baron-Cohen and colleagues gives a quantitative and objective measure. ${ }^{58}$ It assesses the individual's social skills, obsessions, communication and imagination domains on an 18-point scale; James scores 12, above the threshold of ten for a diagnosis of Asperger's syndrome. ${ }^{8} \mathrm{~A}$ detailed review ${ }^{59,60}$ of his psychological traits under these domains is necessary for a definitive diagnosis, but his lack of empathy towards his mother's plight, his alcohol misuse, the failures in his interpersonal relationships and 'the fatal consequences of the first acts of the [English] reign', highlighted by Trevelyan, ${ }^{61}$ are key indicators. 
In an attempt to determine the nature of his cognitive decline in the last five years of James's life, Williams and colleagues used a computer-based linguistics programme to analyse his surviving letters. The programme suggested that his writing might have been influenced by the effects of vascular cognitive impairment, a focal cerebral infarct, or the normal aging processes. ${ }^{62}$

\section{DISCUSSION}

Retrospective diagnosis of historical figures is complicated and problematic, as evidenced by the various theories about Jane Austen's cause of death. Sir Zachery Cope claimed that Austen died of Addison's disease. ${ }^{63} \mathrm{He}$ based his theory on a diary entry on 23 March 1817, some four months before she died:'I am... recovering my looks a little, which have been bad enough, black and white and every wrong colour...'.This is insufficient evidence to diagnose Addison's disease, particularly as there are no extant medical records. We only have the author's own surviving letters, though this did not deter other claims as to the cause of her early death including typhus, tuberculosis, Hodgkin's disease, gastric carcinoma and, recently, arsenic poisoning. The evidence that she was anaemic is convincing but the cause must remain speculative. ${ }^{64}$

In the case of George III, Macalpine and Hunter might have had ulterior motives for suggesting a diagnosis of porphyria and these have been discussed elsewhere. ${ }^{2,5}$ They believed that psychiatric practice should be within the province of neurologists; they opposed the establishment of the Royal College of Psychiatrists and had academic ambitions and specific views on the care and treatment of psychiatric patients. There was also a desire to remove the 'taint of madness from the House of Windsor', and the possibility of success being rewarded with an invitation to Buckingham Palace. The recent finding that they donated several Georgian medals to the Royal Collection may relate to the latter aim. ${ }^{65}$

Computer-based diagnostic instruments have been available for more than 50 years, most notably the Bayesian-based approach developed by de Dombal and colleagues at Leeds. ${ }^{66}$ Their original computer-aided diagnosis of acute abdominal pain programme reliably distinguished six causes of abdominal pain in surgical admissions. It did not include 'medical' causes of pain, including the porphyrias. ${ }^{67}$ The SimulConsult diagnostic decision support system uses an iterative approach to distinguish 2,500 neurological conditions, including the four acute neuro-visceral porphyrias and is now used by the US Library of Medicine. The developer, Dr M Segal, is preparing a detailed review of the basis, applications, benefits and recent and proposed developments of the programme.
The computer-based diagnostic instruments we have described only process the data that are provided, in an objective and reproducible fashion. The conclusions can easily be updated or even overturned by the discovery of new evidence or the re-evaluation of known information, whether about a historical figure's medical history (as in the case of King George III) or a disease process (as with Augustus d'Este and King James). These methods are increasingly being used in clinical practice and we cautiously suggest that this may be extended to retrospective studies.

Caution is however required because of the current limitations of this approach. Firstly, the range of information that can be used with diagnostic databases, particularly those of cardiac, endocrine and metabolic disorders, include laboratory and radiological findings, which would obviously not be available for nineteenthcentury figures. Programmes for aiding the diagnosis of psychiatric, psychological and neurological disorders on the other hand, are often particularly applicable. The interest in programmes for dermatological disorders may also be relevant. ${ }^{68-70}$ Google diagnoses were correct in 15 of 26 patients in a recent New England Journal of Medicine report, a further example of the use of this facility, albeit not specifically designed for this purpose. ${ }^{71}$ Secondly, it is important to use programmes that indicate when there is insufficient data to provide a reliable diagnosis. Systems such as the OPCRIT programme are specifically designed for use with patient case notes and would seem to be particularly appropriate for assessing more recent historical individuals from the twentieth century, where data and information are more readily available. ${ }^{72-4}$ Use of computer-assisted diagnosis will minimise observer bias; input should therefore be done by relevant specialists. This is an early use of this diagnostic approach to historical figures and more detailed protocols still need to be developed. In addition, independent evaluation, perhaps using contemporary figures where there is an accurate diagnosis, will provide additional support for this approach.

\section{TEXTUAL ANALYSIS}

Future developments include the insights that are emerging from 'cognitive archaeology', a term coined by Garrard $^{75}$ to describe systematic retrospective textual analysis as a tool for understanding the earliest stages of slowly progressive neurodegenerative dementias. It was argued that examining samples of language predating the earliest symptoms of cognitive inefficiency may help us to understand the elusive, pre-symptomatic phases of dementia. Unlike memory, attention, or problem-solving, linguistic activity can be, and often is, recorded, surviving in written or spoken format for many years with minimal information decay. One of the best-known studies of retrospective language use involved an extensive archive 
of writings produced by members of a religious community. One of the most remarkable findings of the Nun Study ${ }^{76}$ was that language characteristics of early adulthood impact on the likelihood of developing late life dementia. Later studies have used computer algorithms to characterise large volumes of text and explore how aspects of written language change through the lifetime of a prolific author. When such cases have involved the language of people who are known to have developed Alzheimer's disease, the results are particularly intriguing. ${ }^{77,78}$ In selected cases, similar methods can be applied to archived transcripts of language use - an approach that was used in an attempt to identify early cognitive change in former British Prime Minister, Harold Wilson. ${ }^{75}$

Latent semantic analysis (LSA) is an algorithmic approach to capturing and quantifying the similarity of meaning between two pieces of text. It has been used extensively in the analysis of connected speech in those with schizophrenia and affective illness, indicating that thematic incoherence may be a diagnostically useful marker. Similar methods could be used to assess the changes observed in the correspondence of King George III, and chronologically date both onset and recovery, or even to discover previously unidentified symptomatic periods.

Finally, large volume computerised language analysis that identifies temporal trends in the use of particular words or word types could prove important in recognising and measuring the changes associated with

\section{REFERENCES}

I Peters TJ. The madness of King George III: revelations by James Bland Burges of Nantcribba, Montgomeryshire. Montgomeryshire Collections 2009; 97:63-7I.

2 Peters TJ, Wilkinson D. King George III and porphyria: a clinical re-examination of the historical evidence. Hist Psychiatry 2010; 21:3-19. http://dx.doi.org/10.1 177/0957/54X091026/6

3 Peters TJ, Beveridge A. The madness of King George III: a psychiatric re-assessment. Hist Psychiatry 2010; 21:20-37. http:// dx.doi.org/I0.1 I77/0957/54X09343825

4 Peters TJ, Beveridge A. The blindness, deafness and madness of King George III: psychiatric interactions. J $R$ Coll Physicians Edinb 2010; 40:8I-5. http://dx.doi.org/I0.4997/JRCPE.20I0.II6

5 Peters TJ. King George III, bipolar disorder, porphyria and lessons for historians. Clin Med 20I I; I I:26I-4. http://dx.doi.org/I0.786I// clinmedicine.||-3-26|

6 Garrard P, Peters TJ. Multiple sclerosis or neuromyelitis optica? Re-evaluating an 18th century illness using 2 Ist century software. JRSM Short Rep 2012: 3;I-4. http://dx.doi.org//0.1258/ shorts.2011.011079

7 Garrard, P, Stephenson J, Ganesan V et al. Attenuated variants of Lesch-Nyhan disease: the case of King James VI/I. Brain 20I0 I33:el53. http://dx.doi.org/I0.1093/brain/awqI56

8 Peters TJ, Garrard P, Ganesan V et al. The nature of King James VI/I's medical conditions: new approaches to the diagnosis. Hist Psychiatry 2012; 23:277-90. http://dx.doi.org//0.I I77/0957I54XI I4284I3

9 Macalpine I, Hunter R. George III and the mad business. London:The Penguin Press; 1969. 'hubris syndrome'. This term was recently introduced by David Owen, a medically qualified former British Foreign Secretary, to describe an acquired, stereotypical personality disorder, to which powerful leaders are peculiarly liable to succumb, often with devastating consequences. ${ }^{79}$ Such leaders, particularly those within the political arena, cannot but leave a constantly updating record of written and spoken linguistic data from which future historians with more advanced analytical tools will have much to learn.

\section{CONCLUSION}

Computer-based diagnostic techniques have lent further weight to the case against a diagnosis of porphyria in George III, his grandson August D'Este and James VI and $\mathrm{I}$ and alternative diagnoses have been postulated. Computer-assisted diagnosis may prove to be a valuable additional tool in the diagnosis of illness in historical figures despite the fact that their disease risk may differ from that of a modern population and clinical features may have been interpreted and recorded differently. The use of computers to analyse text offers the intriguing prospect of diagnosing cognitive impairment and affective disorders in historical leaders and assessing their development over time.

\section{Acknowledgements}

We are grateful to Allan Beveridge and John Stephenson for advice and assistance in the selection and inputting of the clinical data.

10 Warren MJ, Jay M, Hunt DM et al. The maddening business of King George III and porphyria. Trends Biochem Sci 1996; 21:229-34.

I I Röhl JCG,Warren M, Hunt D. Purple secret: genes, 'madness' and the Royal houses of Europe. London: Bantam Press; 1998.

12 Cox TM, Jack N, Lofthouse S et al. King George III and porphyria: an elemental hypothesis and investigation. Lancet 2005; 366:332-5. http://dx.doi.org/10.1016/S0140-6736(05)6699/-7

13 Rushton AR. Royal maladies: inherited diseases in the ruling houses of Europe.Victoria, Canada:Trafford Publishing; 2008.

14 Neale G, Hogan H, Sevdalis N. Misdiagnosis: analysis based in case record review with proposals aimed to improve diagnostic processes. Clin Med 20II; II:3 I7-2I. http://dx.doi.org/I0.786I/ clinmedicine. II-4-3 I7

I5 Ray I. Insanity of King George III. American Journal of Insanity I855; XII: I-29.

16 Guttmacher MS. America's last king. An interpretation of the madness of George III. New York: Charles Scribner's Sons; 194I.

17 Guttmacher MS.The "insanity" of George III. Bulletin of the Menninger Clinic 1964;28:101-18. http://dx.doi.org/ I0.1080/09647049709525684

I8 Brownstein S. George III: a revised view of the royal malady.J Hist Neurosci 1997; 6:38-49. http://dx.doi.org/I0.I I36/bmj.I.5479.65

19 Macalpine I, Hunter R. The "insanity" of King George III: a classic case of porphyria. Br Med J 1966; I:65-7I.

20 Macalpine I, Hunter R, Rimington C. Porphyria in the Royal houses of Stuart, Hanover, and Prussia. A follow-up study of George IIl's illness. Br Med J 1968; I:7-18. http://dx.doi.org/ I0.I I 36/bmj. I.5583.7 
2I McGuffin P, Farmer A, Harvey I. A polydiagnostic application of operational criteria in studies of psychotic illness. Development and reliability of the OPCRIT system. Arch Gen Psychiatry I99I; 48:76470. http://dx.doi.org/10.100I/archpsyc.199I.018103200880I5

22 Williams J, Farmer $\mathrm{AE}$, Ackenheil $\mathrm{M}$ et al.A multicentre inter-rater reliability study using the OPCRIT computerized diagnostic system. Psychol Med 1996: 26:775-83. http://dx.doi.org/I0.I0I7/ S003329I70003779X

23 Claridge G. Creativity and madness: clues from modern psychiatric diagnosis. In: Steptoe A, editor. Genius and the mind: studies of creativity and temperament. Oxford: Oxford University Press; 1998. pp. 22850. http://dx.doi.org//0.1093/acprof:oso/9780I98523734.003.00I0

24 Peters TJ,Willis C. Mental health issues of Maria I of Portugal and her sisters: the contributions of the Willis family to the development of psychiatry. Hist Psychiatry. Forthcoming.

25 Young RC, Biggs JT, Ziegler VE et al. A rating scale for mania: reliability, validity and sensitivity. Br J Psychiatry 1978; 133:429-35. http://dx.doi.org/I0.I 192/bjp.133.5.429

26 Bladon FM (editor). The diaries of Colonel the Hon. Robert Fulke Greville equerry to His Majesty King George III. London:John Lane The Bodley Head; 1930.

27 Willis Papers. British Library;Additional MSS. 4I690-41736.

28 Charlson ME, Pompei P,Ales KL et al. A new method of classifying prognostic comorbidity in longitudinal studies: development and validation. J Chronic Dis 1987; 40:373-83. http://dx.doi. org/I0.I0I6/002I-968I(87)90I7I-8

29 Needham DM, Scales DC, Laupacis A et al. A systematic review of the Charlson comorbidity index using Canadian databases: a perspective on risk adjustment in critical care research.J Crit Care 2005; 20: I 2-9. http://dx.doi.org/10.1016/j.jcrc.2004.09.007

30 Tal S, Guller V, Shavit Y et al. Mortality predictors in hospitalized elderly patients. QJM 20I I; 104:933-8. http://dx.doi.org/ 10.1093/qjmed/hcr093

31 Firth D.The case of Augustus d'Esté (1794-1848): the first account of disseminated sclerosis. Proc $R$ Soc Med 194I; 34:38I-4.

32 Firth D. The case of Augustus d'Esté. Cambridge: Cambridge University Press; 1948

33 Butler MA, Bennet TL. In search of a conceptualization of multiple sclerosis: a historical perspective. Neuropsychol Rev 2003; 13:93I 12. http://dx.doi.org/10.1023/A: 1023884322540

34 Compston A, Lassman H, McDonald I. The story of multiple sclerosis. In: Compston A, McDonald IR, Noseworth J et al, editors. McAlpines multiple sclerosis. 4th ed. London: Churchill Livingstone/ Elsevier; 2005. p. 3-68.

35 Landtblom A-M, Fazio P, Fredrikson S et al. The first case history of multiple sclerosis:Augustus d'Esté (1794-1848). Neurol Sci 2010; 3 I:29-33. http://dx.doi.org/ I 0. I007/s I0072-009-0 I6I-4

36 Segal MM. Systems and methods for diagnosing medical conditions. US Patent 6,754,655 issued 22 June, 2004.

37 Segal MM. Mobile medical computing driven by the complexity of neurologic diagnosis. J Child Neurol 2006; 21:595-9. http://dx.doi. org/I0.II77/088307380602I007/60I

38 Segal M. How doctors think, and how software can help avoid cognitive errors in diagnosis. Acta Paediatr 2007; 96: I 720-2. http:// dx.doi.org//0.1 I I I/j. I65I-2227.2007.00480.x

39 Segal M, Leber S. The impact of computer resources on child neurology. In: Swaiman KF, Ashwal S, Ferriero DM et al, editors. Pediatric neurology: principles and practice. 5 th ed. New York: Mosby; 2012. p. 275.

40 Devic E. Myélite subaiguë compliquée de névrite optique. Bulletin Medicale 1894; 8:1033-4. French.

4I Brain Lord. Diseases of the nervous system. 6th ed. London: Oxford University Press; 1962. http://dx.doi.org//0.1016/SI4744422(07)70216-8

42 Wingerchuk DM, Lennon VA, Lucchinetti CF et al.The spectrum of neuromyelitis optica. Lancet Neurol 2007; 6:805-I5. http://dx.doi. org/I0.10I6/SI474-4422(06)7058I-6

43 Orton SM, Herrera BM, Yee IM et al. Sex ratio of multiple sclerosis in Canada: a longitudinal study. Lancet Neurol 2006; 5:932-6. http:// dx.doi.org/I0.1016/SI474-4422(10)70064-8
44 Koch-Henriksen N, Sørensen PS. The changing demographic pattern of multiple sclerosis epidemiology. Lancet Neurol 2010; 9:520-32.

45 Fraser A. Mary Queen of Scots. London:World Books; 1969. http:// dx.doi.org/I0.10I7/S002572730004 I I56

46 Hurst LC. Porphyria revisited. Med Hist 1982; 26:179-82.

47 Beasley AW.The disability of James VI \& I. The Seventeenth Century 1995; 10:151-62.

48 Moore N. The history of the study of medicine in the British Isles. Oxford: Clarendon Press; 1908.

49 Goodall AL. The health of James the Sixth of Scotland and First of England. Medical History 1957; I:17-27. http://dx.doi.org//0.1017/ S002572730002073I

50 Holmes F. The sickly Stuarts. Stroud, Gloucestershire: Sutton Publishing; 2003.

5I Lesch M, Nyhan WL. A familial disorder of uric acid metabolism and central nervous system function. Am J Med 1964; 36:56I-70. http://dx.doi.org/l0.1016/0002-9343(64)90104-4

52 Jinnah HA, De Gregorio L, Harris JC et al. The spectrum of inherited mutations causing HPRT deficiency: 75 new cases and a review of 196 previously reported cases. Mutat Res 2000; 463:30926. http://dx.doi.org/I0.1016/SI383-5742(00)00052-I

53 Jinnah HA, Ceballos-Picot I, Torres RJ et al. Attenuated variants of Lesch-Nyhan disease. Brain 2010; 133:67I-89. http://dx.doi. org/I0.1093/brain/awq013

54 De Mayerne T. Mayerne's note on the health of James I, I Dec. I 723. British Library, Sloane MS 1679. f.42.

55 Gradwohl RBH. Clinical laboratory methods and diagnosis. 2nd ed. London: Henry Kimpton; 1938.

56 McElwee W. The wisest fool in Christendom. The reign of King James I and VI. London: Faber and Faber; 1958.

57 Akrigg GPV (editor). Letters of King James VI \& I. Berkeley, California: University of California Press; 1984. p.3.

58 Baron-Cohen S,Wheelwright S, Robinson J et al.The adult Asperger assessment (AAA): a diagnostic method. J Autism Dev Disord 2005; 35:807-19. http://dx.doi.org//0.1007/s 10803-005-0026-5

59 Cederlund M, Gillberg C. One hundred males with Asperger syndrome: a clinical study of background and associated factors. Dev Med Child Neurol 2004; 46:652-60. http://dx.doi. org/I0.IIII/j.I469-8749.2004.tb00977.x

60 Roy M, Dillo W, Emrich HM et al. Asperger's syndrome in adulthood. Dtsch Artzebl Int 2009; 106:59-64.

6I Trevelyan GM. England under the Stuarts. 2 Ist ed. London: Methuen \& Co.; 1949.pp.6I-3.http://dx.doi.org/I0.I0I7/S0954579400003 I 26

62 Williams K, Holmes F, Kemper S et al. Written language clues to cognitive changes of aging: an analysis of the letters of King James VI/I. J Gerontol B Psychol Sci Soc Sci 2003; 58:42-4. http://dx.doi. org/10.1093/geronb/58.I.P42

63 Cope Z. Jane Austen's last illness. Br Med J 1964; 3: I82-3.

64 Tomalin C. Jane Austen: a life. London: Knopf Doubleday Publishing Group; 2007.

65 Porter R. Psychiatry and its history; Hunter and Macalpine. In: de Goei L, Vijselaar J, editors. Proceedings of the Ist European Congress on the History of Psychiatry and Mental Health and Mental Health Care. Rotterdam: Erasmus Publishing; 1993. pp. 167-77.

66 Horrocks JC, McCann AP, Staniland JR et al. Computer-aided diagnosis: description of an adaptable system, and operational experience with 2,034 cases. $\mathrm{Br}$ Med J 1972; 2:5-9. http://dx.doi. org/I0.1 I36/bmj.2.5804.5

67 de Dombal FT, Leaper DJ, Staniland JR et al. Computer-aided diagnosis of acute abdominal pain. Br Med J 1972; 2:9-13. http:// dx.doi.org/I0.II36/bmj.2.5804.9

68 Stoecker WV. Computer-aided diagnosis of dermatologic disorders. Dermatol Clin 1986; 4:607-25.

69 Potter B, Ronan SG. Computer diagnosis of skin disease. J Fam Pract 1990; 30:201-10.

70 Aksungur VL, Maraki SS, Akman A et al. Computer-aided diagnosis of genodermatoses. J Dermatol 2004; 31:86-93.

7I Tang H, NG JH. Googling for a diagnosis - use of Google as a diagnostic aid: internet based study. $\mathrm{Br}$ Med J 2006; 333: I I43-5. http://dx.doi.org/l 0.I I36/bmj.39003.640567.AE 
72 Post JM, Robins RS. When illness strikes the leader: the dilemma of the captive King. New Haven:Yale University Press; 1993.

73 Davidson JR, Connor KM, Swartz M. Mental illness in US Presidents between 1776 and 1974: a review of bibliographical sources. J Nerv Ment Dis 2006; 194:47-5I. http://dx.doi. org/10.1097/0I.nmd.0000195309.17887.f5

74 Owen D. In sickness and in power. London; Methuen Publishing Ltd: 2008.

75 Garrard P. Cognitive archaeology: uses, methods, and results. Journal of Neurolinguistics 2009; 22:250-4. http://dx.doi.org/10.1016/j. ineuroling.2008.07.006

76 Kemper S, Griener LH, Marquis JG et al. Language decline across the life span: findings from the nun study. Psychol Aging 200I; 16:227-39. http://dx.doi.org//0.1037/0882-7974.16.2.227
77 Garrard P, Maloney LM, Hodges JR et al. The effects of very early Alzheimer's disease on the characteristics of writing by a renowned author. Brain 2005; 128:250-60. http://dx.doi. org/10.1093/brain/awh34l

78 Van Velzen M, Garrard P. From hindsight to insight - retrospective analysis of language written by a renowned Alzheimer's patient. Interdisciplinary Science Reviews 2008; 33: 278-86. http://dx.doi. org/I0.II79//74327908X392852

79 Owen D, Davidson J. Hubris syndrome: an acquired personality disorder? A study of US Presidents and UK Prime Ministers over the last 100 years. Brain 2009; 132: 1396-406. http://dx.doi. org/l0.1093/brain/awp008

\section{Exclusive offer for RCPE Collegiate Members $\mathbf{5 0 \%}$ discount on Fellowship subscriptions}

We are pleased to offer a significant discount in annual subscription rates for eligible Collegiate Members who are Consultants and wish to progress to Fellowship. ${ }^{*}$ Collegiate Members of four years' standing who are successful in their nomination for Fellowship will be able to obtain a $50 \%$ discount on their first year's Fellowship subscription and a $25 \%$ reduction on their second year's subscription, offering savings of up to $£ 300$.

Please access details of our reduced subscription rates, including concessionary elements for Fellows working less than halftime or on maternity leave, at: www.rcpe.ac.uk/join/ fellowshipoffer.php

\section{Fellowship confers a range of additional} benefits and opportunities:

- International peer and public recognition through the use of the 'FRCP Edin' postnominals.

- Professional support for revalidation/ recertification.

- The opportunity to participate in projects and working groups to determine the future direction of education and clinical medicine.

- The opportunity to help maintain national and international clinical standards by acting as an MRCP(UK) examiner.

- The opportunity to inform College responses to external policy consultations in your specialty.

- The opportunity to participate in the governance of the College through election to committees and to Council.

*Eligible candidates should normally have held a substantive Consultant post or equivalent for at least 11 months. If you hold such a post and are interested in being considered for Fellowship, the principal method is nomination by an existing Fellow. Please e-mail Avril Harries at a.harries@rcpe.ac.uk for a list of Fellows in your area. Alternatively, you may wish to discuss nomination with one of our Regional Advisers or consider self-nomination. 